\title{
POLA PENGASUHAN PADA KONTEKS KEMATANGAN EMOSIONAL IBU SINGLE PARENT
}

\author{
Holta Julia $^{1}$, Jarnawi ${ }^{2}$, Syaiful Indra ${ }^{3}$ \\ Universitas Islam Negeri (UIN) Ar Raniry Banda Aceh \\ e-mail: syaiful@konselor.org
}

\begin{abstract}
Every parent has their own parenting style in caring for children, as well as single parent parents certainly have their own parenting style in caring for their children. As a single parent who runs responsibilities that are supposed to be run by two people, it is certainly very burdensome besides having to take care of their children, they also have to work to meet family needs. The method used in this study is descriptive analysis with a qualitative approach and this type of research is field research. The data collection techniques in this study were observation, interviews, and documentation studies. In this study the sampling used a purposive sampling technique with four single parent mothers and four children. From the results of the study it was known that one respondent from the four single parent mothers applied parenting that led to permissive parenting in educating children, due to their busyness as a single parent who ran as two roles so there was not much time to guide and pay attention to children's activities, while three single parent mothers others apply parenting that leads to democratic upbringing with each other, children, care, and also provide sufficient affection and responsibility to children even as a single parent. The obstacles faced by a single parent include two internal and external obstacles, which often occur in a family lacking communication with children and lack of interaction with the community.
\end{abstract}

Keywords: Parenting, Emotional Maturity, Single Parent

\begin{abstract}
Abstrak. Setiap orangtua memiliki gaya pengasuhan tersendiri dalam mengasuh anak, begitu pula dengan orangtua single parent tentu memiliki gaya pengasuhan tersendiri dalam mengasuh anaknya. Sebagai orangtua single parent yang menjalani tanggung jawab yang seharusnya dijalankan oleh dua orang, tentu sangat memberatkan selain harus mengasuh anak mereka juga harus bekerja untuk memenuhi kebutuhan keluarga. Metode yang digunakan dalam penelitian ini adalah deskriptif analisis dengan pendekatan kualitatif dan jenis penelitian ini adalah penelitian lapangan (Field Research). Adapun teknik pengumpulan data dalam penelitian ini adalah observasi, wawancara, dan studi dokumentasi. Dalam penelitian ini pengambilan sampel menggunakan teknik purposive sampling dengan empat ibu single parent dan empat orang anak. Dari hasil penelitian diketahui satu responden dari keempat ibu single parent menerapkan pola asuh yang mengarah pada pola asuh permisif didalam mendidik anak, dikarenakan kesibukannya sebagai single parent yang menjalankan sebagai dua peran sehingga tidak banyak waktu dalam membimbing dan memperhatiakan kegiatan anak, sedangkan tiga ibu single parent lainya menerapkan pola asuh yang mengarah kepada pola asuh demokratis saling terbuka dengan anak, perduli, dan juga memberikan kasih sayang yang cukup serta bertanggung jawab kepada anak walaupun sebagai single parent. Adapun hambatan yang dihadapi oleh single parent antara lain terdiri dari dua hambatan yaitu internal dan eksternal, yang sering terjadi dalam sebuah keluarga kurang komunikasi dengan anak dan kurangnya berinteraksi dengan masyarakat.
\end{abstract}

Kata Kunci: Pengasuban, Kematangan Emosional, Single Parent 


\section{PENDAHULUAN}

Peran keluarga dalam pengasuhan sangat fundamental dalam perkembangan baik fisik maupun psikis anak. Orang tua merupakan refleksi bagi anak-anaknya, oleh sebab itu pengasuhan merupakan sebuah kewajiban yang dilaksanakan oleh keluarga inti. Pada sebuah keluarga, salah satu peran ibu penting. Salah satu peran tersebut dalam hal pendidikan dan penanaman karakter, terlebih pada penanaman sikap kemandirian terhadap sikap. Pendidikan paling awal sebelum anak mendapatkan pendidikan formal disekolah, anak mendapatkan pendidikan dasar yang didapatkan oleh anak pada saat dirumah. Orang tua, merupakan guru yang paling awal mengajarkan pada anak mengenai dasar-dasar kehidupan, seperti sopan santun, interaksi awal dengan sesama serta menanam karakter pada anak. Keluarga merupakan tempat pertama yang dikenal oleh anak untuk sosialisasi dan perkembangan diri (Fadillah, 2015).

Anak termasuk individu unik yang mempunyai eksistensi dan memiliki jiwa sendiri, serta mempunyai hak untuk tumbuh dan berkembang secara optimal sesuai dengan iramanya masing-masing yang khas.Masa kehidupan anak sebagian besar berada dalam lingkungan keluarga. Karena itu, keluargalah yang paling menentukan terhadap masa depan anak, begitu pula corak anak dilihat dari perkembangan sosial, psikis, fisik, dan religiusitas juga ditentukan oleh keluarga. Rasulullah bersabda, yang artinya:

"Tidaklah seorang anak dilabirkan melainkan ia dilabirkan dalam keadaan fitrah, kedua orang tuanya lah yang membuatnya yahudi, nasrani maupun majusi”. (H.R. Bukhari Muslim).

Orangtua mempunyai tanggung jawab untuk mengantarkan putra-putrinya menjadi seorang yang sukses dan bagi orangtua penting memahami dan memperhatikan perkembangan anak (Hidayah, 2009).

Anak adalahkarunia terbesar yang Allah berikan kepada dua insan yang menjalin pernikahan. Anak merupakan harta yang paling berharga bagi keduanya. Namun disisi lain anak adalah amanah yang Allah embankan kepada kedua orang tuanya serta sebagai ujian bagi keduanya. Sebagai firman Allah Surat At-Taghaabun ayat 15.

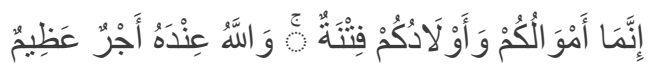

Artinya:"Sesunggubnya hartamu dan anak- anakmu hanyalah cobaan (bagimu), dan di sisi Allab-lah pabala yang besar". 
Pengasuhan yang dilakukan orang tua sangat beperan penting bagi tumbuh kembang anak. Pengasuhan merupakan suatu cara terbaik yang dapat ditempuh orang tua dalam mendidik anaknya sebagai perujudan dari rasa tanggung jawab kepada anaknya sehingga perlakuan orang tua terhadap anaknya memberikan keadilan sangat baik dalam proses pembentukan karakter anak. Setiap orang tua mengharapkan anaknya menjadi anak yang berprilaku baik, oleh karena itu dalam bentuk krakter anak harus diberikan pengasuhan yang baik sejak dini. Hal ini disebabkan karena pendidikan pertama yang diterima oleh anak adalah pendidikan dari orang tua (Aprillia, 2015).

Keadaan orang tua yang sibuk bekerja akan mengurangi waktu kebersamaan bersama anak. Dengan demikian kedekatan orangtua dengan anak menjadi berkurang. Suatu konsekuensi logis dari ibu rumah tangga yang biasanya mendidik anak mulai digantikan perananya oleh pembantu rumah tangga yang terkadang mempunyai banyak permasalahan baik dari segi biaya maupun pengetahuan yang masih sangat rendah dalam mengasuh dan mendidik anak.

Terkait hal yang dijelaskan tentang pentingnya pengasuhan, anak adalah dambaan setiap orang tua yang sudah berkeluarga, karena pada dasarnya anak merupakan calon generasi penerus keturunan dalam setiap keluarga dan sekaligus sebagai pewaris cita-cita bangsa, sehingga anak sangat penting untuk dikembangkan sejak usia yang masih dini. Pendidikan dasar anak pertama kali adalah berasal dari keluarga terutama dari kedua orang tua. Pendidikan yang terarah dengan baik sejak dini terhadap anak yang didasari kasih sayang dari kedua orang tuaakan sangat berpengaruh terhadap perkembangan anak pada periode selanjutnya, dan pada saat inilah akan terbentuk dasar-dasar kepribadian pada anak (Aprillia, 2015).

Dari beberapa pengertian di atas dapat dipahami bahwa pengasuhan anak menjadi sangat penting dalam membentuk karakter, moralitas, pengetahuan, keterampilan, dan life skil yang memadai bagi anak. Oleh sebab itu, kerja sama semua agen sosialisasi baik keluarga, khusus bagi keluarga, tugas dan tanggung jawab dalam menyukseskan pengasuhan anak sejak dini sangat besar, mengingat dari keluargalah seorang anak lahir dan berkembang (Rakhmawati, 2015).

Kematangan mula-mula merupakan hasil dari adanya perubahan-perubahan tertentu dan menyesuaikan struktur pada diri individu, seperti adanya kematangan jaringan-jaringan tubuh, saraf dan kelenjar-kelenjar yang disebut dengan kematangan biologis. Kematangan terjadi pula pada aspek-aspek psikis yang meliputi keadaan berpikir, rasa, kemauan, dan lainlain, serta kematangan pada aspek psikis ini diperlukan adanya latihan latihan tertentu. Misalnya seorang anak yang baru berusia lima tahun dianggap masih belum matang untuk 
menangkap masalah-masalah yang bersifat abstrak, karena itu anak yang bersangkutan belum bisa diberikan matematika dan angka-angka. Pada usia sekitar empat bulan, seoarang anak belum matang didudukan, karena berdasarkan penelitian bahwa kemampuan leher dan kepalanya belum mampu untuk tegak. Usaha pemaksaan terhadap kecepatan tibanya masa kematangan yang terlalu awal mengakibatkan kerusakan atau kegagalan dalam pekembangan tingkah laku individu yang bersangkutan (Desmita, 2005).

Dalam kehidupan sehari-hari sering orang melihat emosi dari sisi negatif. Emosi dinamakan dengan kata-kata emosional yang selnjutnya diwujudkan dalam berbagai perilaku yang tidak baik seperti kata-kata kotor, suara keras, bahkan tingkah laku agresif seperti memukul, memecahkan barang-barang sekelilingnya, dan kata-kata yang menyakitkan hati orang. Pada halemosi dapat juga dilihat dari sisi positif yang bermanfaat bagi kehidupan seseorang.

Goldenson mendifinisikan emosi adalah perasaan yang relatif menetap dalam diri seseorang. Perasaan tersebut biasanya mengarahkan perilakuseseorang, dan perubahanperubahan fisiologik. Goldenson menekankan bahwa emosi dapat memengaruhi perilaku dan fisiologik seseorang (Saam, 2012).

Berdasarkan uraian di atas dapat disimpulkan bahwa kematangan emosi merupakan suatu kondisi pencapaian tingkat kedewasaan dari perkembangan emosi pada diri Individu yang mencapai kematangan emosi di tandai oleh adanya kesanggupan mengendalikan perasaan dan tidak dapat dikuasai perasaan dalam mengerjakan sesuatuatau berhadapan dengan orang lain, tidak mementingkan diri sendiri tetapi mempertimbangkan perasaan orang lain.

Pada zaman sekarang ini banyak konflik-konflik keluarga yang terjadi, yang berakibat keluarga menjadi keluarga single parent, baik itu diantara mereka berpisah karena meninggal dunia maupun berpisah karena perceraian. Orang tua sebagai single parent harus menjalankan peran ganda dalam keluarga untuk kelangsungan hidup keluarganya, terutama bagi seorang ibu yang menjalankan disfungsi keluarganya dalam mendidik anak-anak nya.

Keluarga orang tunggal atau single parent families, yaitu keluarga yang orang tuanya hanya terdiri dari ibu atau ayah yang bertanggung jawab mengurus anak setelah berceraian, mati atau kelahiran anak diluar nikah. Keluarga memiliki peranan yang sangat penting dalam upaya mengembangkan pribadi anak. Perawatan orang tua yang penuh kasih sayang dan pendidikan tentang nilai-nilai kehidupan, baik agama maupu sosial budaya yang diberikannya merupakan faktor yang kondusif untuk mempersiapkan anak menjadi pribadi dan anggota masyarakat yang sehat (Yusuf, 2010). Sedangkan menurut Surya (2003) yang dimaksud orang tua tunggal (single parent) orangtua dalam satu keluarga yang tinggal sendiri yaitu ayah atau ibu saja. Single 
parent dapat terjadi karena perceraian, atau karena salah satu meninggal dunia. Kejadian ini dapat menimpa siapa saja baik muda maupun tua dalam kondisi ayah meninggal dunia. Sehingga ibu menyendiri bersama seluruh anggota keluarganya, atau ibu meninggal dunia sihingga ayah menyendiri bersama dengan keluarganya.

Semua wanita idealnya tak ada yang mau menjadi single parent, karena hal itu bukanlah pilihan melainkan satu kondisi yang tidak mudah dihadapi. Namun pada akhirnya status itu bisa menimpa siapa saja. Entah itu ibu rumah tangga biasa atau wanita karir yang sedang berada di posisi puncak. Status itu bisa terjadi akibat pasangan meninggal dunia, sayap pun terkepak tinggal sebelah, sedangkan kehidupan terus berjalan. Bila seorang ibu tidak kuat dan kokoh maka anak-anaknya akan menderita dan terpuruk. Siap atau tidak siap, menjadi single parent harus dijalani untuk bisa melanjutkan kehidupan ini (Layliyah, 2013).

Berdasarkan hasil penelitian yang telah dilakukan oleh Satria Agus Prayoga mengenai pola pengasuhan anak pada keluarga orang tua tunggal di bandar lampung maka peneliti mendapat kesimpulan bahwa pola pengasuhan pada orang tua tunggal tidak jauh berbeda dengan keluarga yang utuh. Terlihat dari cara komunikasi orang tua dengan anak, prilaku orang tua terhadap anak. Pola pengasuhan yang paling banyak digunakan adalah pola pengasuhan demokratis. Berikut pola yang dipakai para orangtua tunggal : 1) Pola Pengasuhan Demokratis. 2) Pola Pengasuhan Otoriter.3) Pola Pengasuhan Abu-Abu (Prayoga, 2013).

Berdasarkan hasil observasi awal penulis di Kecamatan Johan Pahlawan khususnya Desa Suak Ribee Kabupaten Aceh Barat terdapat beberapa keluarga single parent, semua bekerja dan mengasuh anak seorang diri. Seharusnya dilakukan oleh dua tanggung jawab tetapi dikerjakan oleh satu orang disebabkan karena diantara kedua pasangan telah berpisah, dan penyebab terjadinya perpisahan diantara kedua pasangan dikarenakan mereka sudah tidak ada lagi kecocokan dan memilih untuk bercerai. Seorang anak ingin sekali mendapatkan kasih sayang terhadap kedua orang tuanya, tetapi orang tuanya sendiri sibuk dengan pekerjaanya sehingga tidak mempunyai banyak waktu untuk membimbing dan memperhatikan kegiatan anak-anaknya. Anak mereka tumbuh tanpa banyak pengawasan dari orang. Single parent yang ada di Desa Suak Ribee sebagian tidak bisa mengontrol emosi terhadap anaknya dan masih saja tidak perduli terhadap anak-anaknya, dan kurannya kasih sayang yang diberikan terhadap anak.

Dari permasalahan yang di ceritakan di atas maka peneliti sangat tertarik untuk melakukan lebih lanjut penelitian yang berfokus pada "Pola Pengasuhan Anak di Lihat dari Kematangan Emosional Ibu Single Perent”. Hal ini penting mengingat pada zaman now ini banyak sekali ibu-ibu yang harus mengasuh anak sendiri. 


\section{METODE}

Penelitian ini adalah penelitian lapangan (field research), yaitu suatu penelitian yang dilakukan dengan tujuan langsung kelapangan untuk memperoleh data yang diperlukan. Subjek penelitian ditentukan dengan menggunakan teknik purposive sampling, karena disesuaikan dengan kebutuhan penelitian. Adapun yang menjadi responden dalam penelitian ini adalah keluarga single parent yang ada di Desa Suak Ribee. Sample yang peneliti ambil dalam penelitian ini empat orang ibu single parent, masing-masing dari ibu single parent mempunyai dua orang anak hanya satu dari keempat ibu single parent yang mempunyai tiga orang anak, jadi semua anak single parent terdiri dari sembilan orang anak terdiri dari lima anak laki dan empat anak perempuan, kemudian dua orang masyarakat (tetangga) sebagai informan tambahan. Desa Suak Ribee Kabupaten Aceh Barat. Anak yang peneliti maksud adalah anak yang masih dalam pengasuhan ibunya seperti masih dinafkahi dan masih dalam didikan orangtua. Untuk pengumpulan data dalam penelitian ini, penelitian menggunakan tiga cara yaitu observasi, wawancara, dan studi dokumentasi. Adapun teknik analisis data yaitu Analisis sebelum ke lapangan, Analisis sesudah dilapangan dan penyajian data.

\section{HASIL}

1. Perilaku Anak-Anak yang di Asuh Oleh Ibu Single Parent

Dari hasil wawancara dengan anak HN dilapangan dapat disimpulkan tanggung jawab orang tua $\mathrm{AH}$ dalam mendidikanak-anaknyasangat baik, perhatian dan perduli terhadap aktivitas anak selalu menempatkan waktu untuk pulang kerumah pada waktu siang hari walau pun dalam keadaan sibuk demi menjumpai anaknya.

Hasil wawancara dengan ibu HN maka dapat disimpulan bahwa marah bukan suatu masalah yang bisa diselesaikan, semakin marah anak itu semakin tidak mau mendengar apa yang dikatakan, jadi kalau masalah itu bisa diselesaikan dengan baik maka selesaikanlah dengan baik.

Dari hasil wawancara dengan $\mathrm{N}$ maka dapat disimpulakan semua anak ingin mendapatkan kasih sayang yang betul-betul didapatkan dari seorang ibu, seperti anak-anak yang lainnya, kurangnya perhatian dari orang tua sehingga prilaku anak bersifat negatif, jika orangtua mendidik dan mengasuh anak dengan baik maka anak itu akan berprilaku baik, dan sebaliknya jika anak itu kurang mendapat kasih sayang dan didikannya tidak baik maka 
akan berpengaruh bagi prilaku anak. yang mana anak itu titipan dari Allah untuk dijaga dan disayangi.

Hasil wawancara dengan Ibu ML maka dapat disimpulkan bahwa semakin kita memarahi dan memukul anak maka anak itu semakin nakal dan tidak mau mendengar apa yang dikatakan oleh orangtua. jadi sebagai orangtua harus betul-betul bisa mendidik anak itu dengan baik dan terus memberikan motivasi kepada anak. Supaya anak itu bisa mengetahui mana yang dikerjakan itu benar dan mana yang salah. Sebagai orangtua harus selalu memberikan waktu yang banyak untuk anak, dan harus memberi kanperhatian dan kasih sayang yang cukup.

Dari hasil wawancara dengan MR maka dapat disimpulkan mana orangtua tidak marah jika anak itu melakukan kesalah, semua orangtua manapun ketika anak itu melakukan kesalahan pasti marah, cara orangtua mendidik anak pasti berbeda-beda, ketika anak tidak berbuat salah pasti tidak akan memarahinya. Dan mana orangtua yang tidak sayang dengan anaknya semua orangtua sayang dan ingin membuat anaknya itu menjadi anak yang sukses.

Hasil wawancara dengan ibu NH maka dapat disimpulkan kita sebagai orangtua harus lebih memperhatikan anak-anak, karena sangat penting memberikan perhatian kepada anak apa lagi anak dari single parent yang mana anak-anak dari single parent itu mereka hanya mendapat kasih saya dari seorang ibu tidak seperti anak yang lain mendapatkan kasih sayang yang utuh dari orangtunya. Tetap menjadi seorang ibu yang bertanggung jawab didalam mendidik anak-anak.

Dari hasil wawancara dengan ID dapat disimpulkan bahwa sangat baik orangtuanya memberikan kasih sayang, perhatian dan tanggung jawab walaupun sebagai single parent. Selalu memberikan motivasi kepada anak dan mendukung anak disaat anak itu melakukan apapun yang disukai, dengan didikan yang diberikan ibu single parent yang baik maka anakanak akan menjadi anak yang baik dan penurut.

Hasil wawancara dengan ibu DW maka dapat disimpulkan bahwasan anak-anak itu cuma ingin mendapatkan kasih sayang dari orangtuanya yang penuh, perhatian yang lebih dan mendidiknya dengan baik. maka jika semua terpenuhi anak itu tidak akan kekurangan apapun dan tidak akan membuat hal-hal yang akan mengecewakan kita, karena kenapa, kasih sayang yang didapatkan anak itu perhatian dan didikan yang bagus sudah membuat mereka sadar bahwa mereka hanya mempunyai seorang ibu yang sudah membesarkan mereka dari kecil hingga sekarang dengan sendiri tanpa adanya sok-sok seorang ayah yang membantu. 
2. Prestasi Belajar Anak yang di asuh oleh ibu single parent

Hasil wawancara dengan ibu HN maka dapat disimpulkan mengawasi anak-anak didalam melakukan kegiatan-kegiatan apa saja sangat penting dan sudah memang kewajiban dari orangtua, dan harus selalu memberikan anak-anak itu waktu bermain walaupun dalam pengawasan orangtua. Dan tidak boleh juga terlalu mengekang anak itu bisa berdampak buruk bagi anak. Kemudian teruslah memotivasi anak supaya kedepanya anak itu bisa menjadi orang yang baik dan berguna bagi siapa saja.

Hasil wawancara dengan ibu MLmaka dapat disimpulkan seorang anak itu ingin sekali mendapatkan kasih sayang yang penuh dari orangtuanya apalagi anak yang dibesarkan dari keluarga single parent, terutama dari ibu single parent, berat bagi single parent itu di dalam mengasuh anaknya tanpa adanya sok-sok suami yang mendapinginya. Yang mana tanggung jawab hanya dilakukan oleh seorang ibu single parent, dan harus menjadi dua peran sebagai ayah dan sebagai ibu didalam memberikan kasih sayang terhadap anak.

Hasil wawancara ibu NH maka dapat disimpulakan selalu memberikan anak itu semangat dan memotivasi anak supaya kedepannya bisa sukses, dan selalu memberikan dan mengontrol anak disaat bermain. Juga selalu memberikan banyak waktu bersama anak-anak, baik dalam berkomunikasi maupun dalam mengasuh anak.

Hasil wawancara ibu DW maka dapat disimpulakan, pengasuhan yang diberikan sangat baik dan selalu bisa mengawasi anak-anak didalam bermain maupun didalam belajar. Selalu memberikan waktu untuk berbincang-bincang dengan anak dan selalu memberikan apa yang anak inginkan, dengan kasih sayang yang diberikan supaya anaknya itu tidak merasa kurang mendapatkan kasih sayang.

3. Faktor Penghambat yang Dihadapi Oleh Ibu Single Parent dalam Pengasuhan Anak

Hasil wawancara dari ibu $\mathrm{HN}$ maka dapat disimpulkan bersiraturahmi dengan masyarakat apa lagi dengan tetangga itu sangat penting, karena kita bisa berbagi dan saling bertukar pendapat. Kemudian tidak ada kendala ketika mengasuh anak dan tidak ada kendala di keuangan, terlalu terpenuhi apapun yang diinginkan anak. Sebagai orangtua ya harus berusaha dalam membesarkan anak apa lagi orangtua sebagai single parent yang bekerja sendiri demi anak-anak.

Hasil wawancara dengan ibu ML maka dapat disimpulkan tidak pernah ada waktu dalam berinteraksi dengan masyarakat, karena sibuk dengan pekeraan demi menghidupi anak, sehingga jarang sekali untuk pergi dan jarang sekali duduk dengan tetangga tidak 
seperti orang-orang. Dengan giat seperti ini Insya Allah tidak ada kekurangan dalam segala hal termasuk didalam keungan.

Hasil wawancara ibu NH maka dapat disimpulakan bahwa seorang single parent itu harus bekerja dengan yakin untuk menghidupi anak-anaknya, supaya anaknya tidak merasa kukurangan dan selalu terpenuhi apa yang diinginkan anak. Tanpa seorang ayahpun seorang ibu ini bisa menjalankan tanggung jawabnya dan bisa memuhi kebutuhan anak nya tidak ada kendala sama sekali walaupun mengasuh anak sendiri.

Hasil wawancara dengan ibu DW maka dapat disimpulkan jarang untuk keluar apa lagi bergabung dengan masyarakat tidak pernah lebih baik dirumah dengan anak-anak dari pada duduk diluar dengan tetangga. Dan dengan hasil yang didapatkan tidak pernah merasa kekurangan, apapun yang diinginkan anak selalu terpenuhi. Dengan tidak adanya kehadiran seorang suami bisa mendidik dan membesarkan anak dengan sendiri dan hasil keringat sendiri.

Dari hasil wawancara dengan tetangga 1 dapat disimpulakan bahwa sangat bertanggung jawab single parent tersubut didalam mengasuh anaknya sangat jauh beda dengan keluarga yang utuh. Single parent itu juga bisa memberikan didikan yang tinggi terhadap anak-anaknya meski dia mengasuh sendiri tanpa ada suami yang ikut membantunya.

Dari hasil wawancara dengan tetangga 1 dapat disimpukan pengasuhan yang dilakukan oleh single parent yang ada di Desa Suak Ribee berbeda-beda ada yang mengasuhnya baik dan ada yang kurang baik, karena sibuk bekerja sehingga anaknya mendapat perhatian yang kurang dari orangtunya.danada juga yang mendapatkan kasih sayang dan perhatian yang lebih dari orang tuanya sehingga anaknya itu menampilkan prilaku yang baik.

Dari Hasil Observasi ke empat keluarga single parent yang ada di Desa Suak Ribee terdapat satuwanita single parent yang tidak bisa mengontrol dan menahan emosi dalam mengasuhanaknya, penuh dengan amarah dan bisa juga menimbulkan kekerasan terhadap anak. Penyebab kurangnya perhatian wanita single perent terhadap anaknya dikarenakan wanita single parent tersebut sibuk mementingkan pekerjaanya. Sehingga anaknya tidak mendapat perhatian dan kasih sayang oleh ibunya, juga tidak ada waktu kebersamaan dengan anaknya dirumah. Dengan kurangnya perhatian dan kasih sayang yang diberikan terhadap anak sehingga timbul prilaku terhadap anak yang tidak baik, seperti selalu bermasalah baik disekolah maupun dikalangan tempat tinggalnya. Single parent ini juga mengeluarkan kata-kata yang tidak wajar didengar oleh anaknya seperti mengeluarkan kata- 
kata bodoh, memanggil anak dengan sebutan kamu atau ke kemudian ketika memerintah menggunakan intonasi yang tinggi. Perhatian dan kasih sayang yang diberikan kepada anak kurang baik dari segi makan, waktu bermain dan waktu istirahat tidak teratur.Prilaku yang seperti itu yang ditampilakan oleh seorang anak dari ke empat wanitasingle parent yang ada di Desa Suak Ribee yang kurang mendapatkan perhatian dari seorang ibunya.

Sedangkan ketiga dari keempat wanita single parent tersebut masing masing mempunyai anak. Ke tiga wanita single parent tersebut juga sibuk dengan pekerjaannya. Tetapi ketiga wanita single parent tersebut didalam mengasuh anak mereka sangat baik dan mereka juga mempunyai banyak waktu dirumah bersama anak mereka. Sehingga anak dari ketiga single parent tersebut mendapatkan perhatian yang sangat baik dan kasih sayang yang lebih. Sehingga anak dari ketiga single parent tersebut berprilaku sangat baik, sopan terhadap siapapun dan tidak pernah membuat kesalahan baik disekolah maupun di rumah.

\section{PEMBAHASAN}

1. Perilaku Anak-Anak yang di Asuh Oleh Ibu Single Parent

Single parent di Gampong Suak Ribee menjadi pengasuh dan pembimbing dalam keluarga. Orangtua sangat berperan dalam meletakan dasar-dasar perilaku bagi anakanaknya. Sikap, perilaku, dan kebiasaan orangtua selalu dilihat, dinilai dan ditiru oleh anaknya yang kemudian semua itu secara sadar atau tidak sadar diperoleh dan kemudian menjadi kebiasaan pula bagi anak-anaknya. Hal demikian disebabkan karena anak mengidentifikasi diri pada orangtua sebelum mengadakan identifikasi dengan orang lain.

Ada satu keluarga single parent yang terdapat di Gampong Suak Ribee menggunakan pola asuh otoriter yang diberikan kepada anak-anaknya. Komunikasi dengan anak cenderung menggunakan kata-kata yang kasar, baik dalam memerintah maupun disaat berbicara dengan anak. Sehingga timbul prilaku negatif terhadap anak, seperti membantah apa yang dikatakan ibunya, tidak mau mendengar, pulang sekolah tidak tepat waktu dan suka meganggu adiknya disaat adiknya bermain. Seorang anak itu akan berprilaku baik apabila didikan dari orang tuanya juga baik.

Pada Gampong Suak Ribee single parent cenderung tidak perduli dalam mengurus anak seperti tidak mengawasi anak dalam bergaul, makan dan waktu istirahat anak-anaknya tidak teratur, kebersihan dan waktu belajar anak tidak ditetapkan dalam keluarga menjadi kebiasaan rutin yang seharusnya menjadi tanggung jawab anak untuk dilakukannya supaya ada keteraturan dalam hidupnya. Anak memiliki kebiasaan yang tidak teratur dalam hidupnya disebabkan karena orang tuanya terlalu cuek dan tidak peduli terhadap kegiatan 
sehari-hari yang dilakukan anak sehingga kebiasaan tersebut berpengaruh terhadap kepribadian anak seperti tidak disiplin, tidak bertanggung jawab dalam melakukan suatu hal serta cenderung tidak peduli pula terhadap lingkungan sekitarnya.

Pada tiga keluarga single parent dalam mengasuh dan mendidik anak-anaknya bersifat demokratis. Dengan kasih sayang yang diberikan oleh ibu single parent dan keperdulianya terhadap anak-anaknya maka timbulah prilaku positif terhadap anak, Hal ini dapat dilihat dari sikap anaknya yang patuh dan penurut pada orang tuanya, tidak mengganggu adikadiknya, ketika bermain tidak larut waktu, anak mengetahui waktu belajar dan mengaji dan langsung mengerjakannya tanpa harus disuruh oleh orang tuanya, kebersihan diri terjaga serta peka terhadap kondisi dan keadaan orang tuanya meskipun mereka diasuh tanpa kehadiran seorang ayah. Adapun kasih sayang yang diberikan oleh orangtua terhadap anak selalu terpenuhi, memberikan perhatian yang lebih, dan selalu mempunyai waktu bersama anak-anaknya seperti menanyakan anaknya saat ia pulang sekolah, dan disaat waktu makan.Sehingga dari itu anak dari single parent tersebut berperilaku sangat baik, baik disekolah maupun di masyarakat.

Menurut Baumrind dalam bukunya Muhammad Takdir Ilahi mengatakan ada tiga macam pola asuh orang tua, yaitu:

a) Pola Asuh Otoriter

Pola asuh ini cenderung menetapkan standar yang mutlak harus dituruti, biasanya dibarengi dengan ancaman-ancaman. Orang tua tipe ini cenderung memaksa, memerintah, menghukum. Apabila anak tidak mau melakukan apa yang dikatakan oleh orang tua, maka orang tua tipe ini tidak segan menghukum anak. Orang tua tipe ini juga tidak juga mengenal kompromi dan dalam komunikasi biasanya bersifat satu arah. Orang tua tipe ini tidak memerlukan umpan balik dari anaknya untuk mengerti mengenai anaknya.

\section{b) Pola Asuh Permisif}

Pola asuh permisif adalah jenis pola asuh anak yang cuek terhadap anak. Jadi, apapun yang akan dilakukan anak diperbolehkan seperti tidak sekolah, bandel, melakukan banyak kegiatan maksiat, pergaulan bebas negatif, materialistis, dan sebaginya. Pola asuh orang tua permisif bersifat terlalu lunak, tidak berbahaya, memberi kebebasan terhadap anak tanpa adanya norma-norma yang harus diikuti oleh mereka.

Akibatnya anak tumbuh menjadi seorang yang berprilaku agresif dan anti sosial, karena sejak awal dia tidak diajari untuk patuh pada peraturan sosial. Dalam hal ini anak dianggap mampu berpikir sendiri.selain itu ketidak acuhan orang tua mengembangakan emosi anak 
yang tidak stabil pada anak memberikan kebebasan sepenuhnya kepada anak untuk melakukan sesuatu sesuai kehendaknya tidak adanya pengawasan, bahkan cenderung membiarkan anak tanpa nasehat dan arahan (Ilahi).

\section{c) Pola Asuh Demokratis}

Pola dimana anak diberi kesempatan untuk menyampaikan pendapat, gagasan maupun keinginannya. Jadi, anak dapat berpartisipasi dalam penentuan keputusan-keputusan dalam keluarga dengan batas-batas tertentu. Pola asuh demokratis ini di tandai dengan adanya sikap terbuka antara orang tua dan anak. Mereka membuat aturan yang disetujui bersama. Anak diberi kebebasan untuk mengemukakan pendapat, perasaan, keinginannya. Jadi, dalam pola asuh ini terdapat komunikasi yang baik antara orang tua dan anak.

2. Prestasi Belajar Anak yang di Asuh oleh Ibu Single Parent

Single parent di Gampong Suak Ribee menjadi pengasuh dan pembimbing dalam keluarga. Orangtua sangat berperan dalam meletakan dasar-dasar perilaku bagi anakanaknya. Sikap, perilaku, dan kebiasaan orangtua selalu dilihat, dinilai dan ditiru oleh anaknya yang kemudian semua itu secara sadar atau tidak sadar diperoleh dan kemudian menjadi kebiasaan pula bagi anak-anaknya. Hal demikian disebabkan karena anak mengidentifikasi diri pada orangtua sebelum mengadakan identifikasi dengan orang lain.

Satu anak dari single parent yang terdapat di Desa Suak Ribee Kabupaten Aceh Barat memiliki prestasi belajar yang rendah, dikarenakan anak tersebut tidak pernah mau belajar, malas ketika disuruh oleh ibunya, dan tidak pernah konsen ketika dia mau belajar. Dengan prestasi anak ini yang malas belajar sehingga anak ini selalu mendapatkan nilai yang jelek disekolah. Kemudian orangtua dari anak tersebut cara mendidik anaknya dengan ancaman dan ketika anak tidak mau belajar maka tidak dikasih uang jajan, tidak dikasih bermain, maka dari itu anak dari single parent belajar bukan karena niat buat belajar dengan serius tetapi dikarenakan ancaman dari ibunya.

Pada tiga keluarga single parent dalam mengasuh dan mendidik anak-anaknya bersifat demokratis. Hal ini dapat dilihat dari sikap anaknya yang patuh dan penurut pada orang tuanya, tidak mengganggu adik-adiknya, ketika bermain tidak larut waktu, anak mengetahui waktu belajar dan mengaji dan langsung mengerjakannya tanpa harus disuruh oleh orang tuanya, kebersihan diri terjaga serta peka terhadap kondisi dan keadaan orang tuanya meskipun mereka diasuh tanpa kehadiran seorang ayah. Adapun kasih sayang yang diberikan oleh orangtua terhadap anak selalu terpenuhi, memberikan perhatian yang lebih, 
dan selalu mempunyai waktu bersama anak-anaknya seperti menanyakan anaknya saat ia pulang sekolah, dan disaat waktu makan.Sehingga prestasi belajar pada 3 anak keluarga single parent tersebut sangat baik, berprestasi disekolah maupun didalam rumah tangga.

Menurut Baumrind dalam bukunya Muhammad Takdir Ilahi mengatakan ada tiga macam pola asuh orang tua, yaitu:

a) Pola Asuh Otoriter

Pola asuh ini cenderung menetapkan standar yang mutlak harus dituruti, biasanya dibarengi dengan ancaman-ancaman. Orang tua tipe ini cenderung memaksa, memerintah, menghukum. Apabila anak tidak mau melakukan apa yang dikatakan oleh orang tua, maka orang tua tipe ini tidak segan menghukum anak. Orang tua tipe ini juga tidak juga mengenal kompromi dan dalam komunikasi biasanya bersifat satu arah. Orang tua tipe ini tidak memerlukan umpan balik dari anaknya untuk mengerti mengenai anaknya.

b) Pola Asuh Permisif

Pola asuh permisif adalah jenis pola asuh anak yang cuek terhadap anak. Jadi, apapun yang akan dilakukan anak diperbolehkan seperti tidak sekolah, bandel, melakukan banyak kegiatan maksiat, pergaulan bebas negatif, materialistis, dan sebaginya. Pola asuh orang tua permisif bersifat terlalu lunak, tidak berbahaya, memberi kebebasan terhadap anak tanpa adanya norma-norma yang harus diikuti oleh mereka.

Akibatnya anak tumbuh menjadi seorang yang berprilaku agresif dan anti sosial, karena sejak awal dia tidak diajari untuk patuh pada peraturan sosial. Dalam hal ini anak dianggap mampu berpikir sendiri.selain itu ketidak acuhan orang tua mengembangakan emosi anak yang tidak stabil pada anak memberikan kebebasan sepenuhnya kepada anak untuk melakukan sesuatu sesuai kehendaknya tidak adanya pengawasan, bahkan cenderung membiarkan anak tanpa nasehat dan arahan (Ilahi).

Pada Gampong Suak Ribee single parent cenderung tidak perduli dalam mengurus anak seperti tidak mengawasi anak dalam bergaul, makan dan waktu istirahat anak-anaknya tidak teratur, kebersihan dan waktu belajar anak tidak ditetapkan dalam keluarga menjadi kebiasaan rutin yang seharusnya menjadi tanggung jawab anak untuk dilakukannya supaya ada keteraturan dalam hidupnya. Anak memiliki kebiasaan yang tidak teratur dalam hidupnya disebabkan karena orang tuanya terlalu cuek dan tidak peduli terhadap kegiatan sehari-hari yang dilakukan anak sehingga kebiasaan tersebut berpengaruh terhadap kepribadian anak seperti tidak disiplin, tidak bertanggung jawab dalam melakukan suatu hal serta cenderung tidak peduli pula terhadap lingkungan sekitarnya. 
c) Pola Asuh Demokratis

Pola dimana anak diberi kesempatan untuk menyampaikan pendapat, gagasan maupun keinginannya. Jadi, anak dapat berpartisipasi dalam penentuan keputusankeputusan dalam keluarga dengan batas-batas tertentu. Pola asuh demokratis ini di tandai dengan adanya sikap terbuka antara orang tua dan anak. Mereka membuat aturan yang disetujui bersama. Anak diberi kebebasan untuk mengemukakan pendapat, perasaan, keinginannya. Jadi, dalam pola asuh ini terdapat komunikasi yang baik antara orang tua dan anak.

\section{Faktor Penghambat yang Dihadapi Oleh Ibu Single Parent}

Keluarga dari single parent di Gampong Suak Ribee merupakan suatu keluarga yang tidak utuh yang diakibatkan karena adanya perpisahan perceraian atau perpisahan karena kematian. Kesiapan dalam proses penerimaan diri ibu sebagai kepala keluarga akan membutuhkan waktu. Bagi ibu yang terpisah dengan suaminya karena bercerai hal itu dianggap sesuatu hal yang tidak begitu berat dalam melakukan penerimaan diri, sedangkan ibu yang ditinggalkan suaminya karena meninggal dunia akan membutuhkan proses yang panjang akibat kehilangan salah satu figur ayah/suami yang dahulunya menjadi tulang punggung keluarga, baik sebagai pencari nafkah maupun bertanggung jawab penuh atas keluarganya.

Pada keluarga single parent di Gampong Suak Ribee, kini seluruh beban keluarga dilimpahkan kepada salah satu orangtua yaitu ibu, kesulitan dan kesedihan dinilai namun ibu tetap berusaha terus bangkit demi menjalani kewajibanya, sebagai orangtua, dalam keluarga single parent kesendirian mereka dalam mengasuh anak menimbulkan berbagai permasalahan dari permasalahan hilangnya salah satu figur orangtua yaitu ayah.

Dari ke empat ibu single parent ada satu ibu single parent diantaranya yang memiliki pemikiran yang negatif terhadap kondisi dan situasi dirinya sebagai single parent. Hal ini disebabkan karena single parent itu pernah didatangai dan ditegur oleh kepala lorong, karena seringnya datang tamu laki-laki kerumah. Jadi menurut single parent itu masyarakat sudah menilai jelek tentang dirinya, oleh karena itu ibu single parent dalam melakukan interaksi sosial dengan lingkungan sekitarnya, oleh karena itu dia lebih memilih lebih berdiam diri dirumah hambatan bagi dirinya. Sedangkan ketiga ibu single parent lainnya mereka tidak memiliki hambatan atau kendala-kendala didalam berbaur dengan masyarakat baik dalam berinteraksi, berkomunikasi bahkan didalam mengikuti kegiatan-kegiatan tidak ada sama 
sekali hambatan. Masyarakat pun menanggapi dan menilai ke tiga ibu single parent itu sangat baik.

Dari keempat single parent yang ada di Desa Suak Ribee bahwa tidak ada sama sekali hambatan atau kendala-kendala yang dihadapi dari segi ekonomi atau keuangan. Semua single parent ini masing-masing bekerja dengan sendiri masing-masing single parent ini ada yang bekerja sebagai pagawai dan sebagiannya lagi memiliki usaha sendiri seperti usaha kecil-kecilan, yaitu tokoh baju, kelontong dan bahkan mempunyai bengkel yang dikelola oleh adik single parent itu sendiri. Dengan mengasuh dan bekerja demi menafkahi anak seorang diri tanpa adanya bantuan dari seorang ayahnya single parent itu mampu memenuhi kebutuhan rumah tangganya, dan juga mampu menyekolahkan anak-anaknya, bahkan keinginan anaknya itu terpenuhi, seperti memberikan playstation game, membelikan sepeda bahkan mengajak anak jalan-jalan.

Dari keempat single parent dua dari ibu single parent mempunyai didikan yang tinggi, ibu single parent yang pertama jenjang pendidikan terakhir S1 dan ibu single perent yang kedua jenjang pendidkan terakhir SMA, tetapi keduanya itu bekerja sebagai PNS. Sedangkan dua orang lainya memiliki pendidikan yang rendah seperti tamatan SMA, yang bekerja sebagai pedagang kecil-kecilan.

Pendidikan orangtua tidak secara mutlak mempengaruhi cara mengasuh dan mendidik anak, sepeti yang terdapat pada tiga keluarga single parent di Gampong Suak Ribee yang jenjang pendidikan terakhir orang tuanya tamatan SMA mereka tetap baik di dalam mengasuh anaknya. Hal ini dapat di lihat melalui kepribadian anak yang dalam kesehariannya memiliki sikap dan prilaku yang positif seperti selalu mendengar perkataan orangtua tanpa bantahan, memiliki prestasi yang baik di sekolah, bersungguh dalam belajar dan mengaji serta dapat menjaga dan menyayangi adiknya di rumah ketika ibunya bekerja.

Satu keluarga single parent yang orang tuanya pendidikan terakhir SMA tetapi bekerja sebagai PNS di lembaga pemerintahan kementrian pekerjaan umum (PU). Ibu single parent ini memiliki hubungan komunikasi yang kurang baik dengan anak-anakanya hal ini bukan disebabkan oleh tingkat pendidikan orang tua saja akan tetapi karakter individu juga mempengaruhi dalam mengasuh dan mendidik anak. Karakter yang dimiliki ibu single parent ini cenderung tidak perhatian, tidak peduli, cepat marah. Sehingga anak-anaknya berprilaku negatif seperti tidak kenal waktu dalam bermain, melawan dengan orangtua, aktivitas keseharian tidak teratur seperti makan, tidur, belajar, mandi, dan sering mengganggu adiknya yang menyebabkan ibunya selalu berteriak. Penyebab timbulnya emosional pada ibu single parent dikarenakan dirinya belum bisa menerima situasi dan kondisi sebagai single 
parent karena masih mengingat masa lalu terkait ditinggal cerai oleh suaminya karena perselingkuhan, sehingga single parent ini tertekan dan perpengaruh terhadap pengasuhan yang diberikan kepada anak.

Kendala-kendala dan permasalahan yang dihadapi oleh single parent dalam pengasuhan anak.

a. Sosial Kultural.

Sosial budaya merupakan bagian hidup manusia yang paling dekat dengan kehidupan sehari-hari. Setiap kegiatan manusia hampir tak pernah lepas dari unsur sosial budaya. Sebab sebagian besar dari kegiatan manusia dilakukan secara kelompok. Manusia adalah makhluk sosial, dimana manusia itu senang bergaul dan berinteraksi dengan manusia lain didalam kehidupan bermasyarakat maupun berinteraksidengan lingkungannya. Semua interaksi sosial yang dilakukan seorang individu memunculkan emosi dalam diri setiap individu, dari emosi tersebut kemudian individu dapat menentukan sikap dan pikiran sehingga mampu bertindak sesuai dengan dirinya (Hayati \& Indra, 2018).

\section{b. Sosial Ekonomi}

Sosial ekonomi adalah kedudukan atau posisi seseorang dalam kelompok masyarakat yang ditentukan oleh jenis aktifitas ekonomi, pendidikan serta pendapatkan. Dalam pembahasannya soial dan ekonomi sering terjadi objek pembahasan yang berbeda. Dalam konsep sosiologi manusia sering disebut dengan makhluk sosial yang artinya manusia tidak dapat hidup wajar tanpa adanya bantuan dari orang lain, sehingga arti sosial sering di artikan sebagai hal yang berkenaan sebagai masyarakat. Dalam mengasuh dan mendidik anak memang membutuhkan ekonomi yang cukup, karena ekonomi merupakan penunjang kehidupan jika ekonomi lemah otomatis ekonomi juga akan menjadi kurang baik.

\section{c. Rendahnya Pendidikan Orangtua.}

Pendidikan adalah sebagai usaha sadar dan terencana untuk meujudkan suasana belajar dan proses pembelajaran untuk peserta mengembangkan potensi dirinya untuk memiliki kekuatan spirituan keagamaan, pengendalian diri, kepribadian, kecerdasa, akhlak mulia, serta ketrampilan yang diperlukan dirinya dan masyarakat. Pendidikan dapat diartikan sebagai usaha sadar dan sistematis untuk mencapai taraf hidup atau untuk kemajuan lebih baik. secara sederhana pendidikan adalah proses pembelajaran bagi peserta didik untuk dapat mengerti, paham, dan membuat manusia lebih krits dalam berfikir. 
Pendidikan yang diberikan oleh orangtua sangat berpengaruh terhadap perkembangan anak, jika orang tua memberikan pendidikan yang baik maka anak tersebut juga akan menjadi anak yang baik dan berkepribadian yang baik, pendidikan orang tua juga sangat berpengaruh terhadap anak jika memiliki pendidikan yang buruk bagaimana orangtua itu akan mampu mendidik dan mengasuh anaknya dengan

\section{SIMPULAN}

Berdasarkan deskripsi dan pembahasan data penelitian, maka dapat dikatakan pola pengasuhan anak di lihat dari kematangan emosional ibu single parentsudah matang secara emosional, pernyatann ini didasari dari temuan peneliti yaitu:

Pertama, dilihat dari prilaku anak yang diasuh oleh ibu single parentsama saja dengan anak yang lain yang orangtua yang masih utuh yaitu berprilaku yang baik, patuh, rajin, bertutur kata yang sopan baik kepada orangtua maupun temanya, tidak mengganggu adik-adiknya.

Kedua, dilihat dari prestasi belajar anak yang di asuh oleh ibu single parenthampir ratarata berprestasi baik, pernyataan ini dapat dilihat ketika anak mendapat ranking di kelas yang diketahui melalui hasil rapor.Pernyataan dari guru menyatakan bahwa anak single parent aktif di dalam kelas ketika belajar baik pada saat berdiskusi kolompok maupun mengerjakan tugas individu. Pernyataan dari orangtuanya menyatakan bahawa anak sudah mulai mengetahui waktu belajar dan mengaji, sehingga langsung mengerakannya tanpa harus disuruh oleh orang tua.

Ketiga, dilihat dari hambatan yang dihadapi oleh ibu single parentbanyak sekali, namun didalam mengasuh anaknya tetap baik, walaupun dirinya berperan sebagai ayah dan ibu dalam mengasuh dan mendidik anaknya.

\section{REFERENSI}

Abdurrahman Fathoni. (2006). Metodologi Penelitian dan Teknik Penyusunan Skripsi, Jakarta: Rineka Cipta.

Atria Agus Prayoga. (2013). Pola Pengasuban Anak Pada OrangTua TUnggal, Skripsi, Jurusan Sosiologi, Falkutas Ilmu Sosial Dan Politik, Universitas Lampung.

Bimo Walgito. (1994). Pengantar Psikologi Umum, Yogyakarta, Andi Offset, 1994

Burhan Bungin. (2001). Metodelogi Penelitian Sosial Format-format Kuantitatif dan Kualitatif, Surabaya: Airlangga University Press. 
Departemen Agama RI. (2009). Mushaf Al-Qur'an dan Terjemah, Jakarta: Pustaka AlKausar.

Desmita. (2005). Psikologi Perkembangan, Bandung: PT Remaja Rosdakarya.

Hayati, I., \& Sujadi, E. (2018). Perbedaan Keterampilan Belajar Antara Siswa IPA dan IPS. Tarbawi : Jurnal Ilmu Pendidikan, 14(1), 1-10. doi:10.32939/tarbawi.v14i1.250

Hasbiansyah, Walkito, Patrisia Cintani Widowati. (2009). Hubungan Antara Kematangan Emosi Dengan Perilaku Seksual Pranikah Pada Remaja Akbir, Skripsi, Jurusan Psikologi, Falkutas Psikologi, Universitas Sanata Dharma Yogyakarta.

Hanimah, Peran Ibu Sebagai Orang Tua Tunggal (Singel Perent) dalam Menanamkan Pendidikan Agama Terbadap Anak di Lingkungan Keluarga, diunduh dari http://Jurmafis. Untan.ac.id pada tanggal 02 April 2015.

Istina Rakhmawati. (2015). Peran Keluarga Dalam Pengasuahan Anak, Jurnal Bimbingan dan Konseling Islam, Vol.6, No.1, Juni 2015.

Nawawi H.Hadari. (2005). Metode Penelitian Bidang Sosial, Yokyakarta: Gajah Mada University Press, 2005.

Nur Fadillah. (2015). Peran Ibu Single Parent Dalam Menumbubkan Kemandirian Anak Di Desa Bojong Timur Mangelang, Skripsi Jurusan Politik Dan Kewarganegaraan Fakultas Ilmu Sosial Universitas Negeri Semarang.

Mohammad Surya. (2003). Bina Keluarga, Semarang: Aneka Ilmu.

Rifa Hidayah. (2009). Psikologi Pengasuban Anak, Malang: Uin Malang Press.

Rini hayati \& Syaiful Indra. (2018). Hubungan Marah dengan Perilaku Agresif pada Remaja, Jurnal Edukasi Bimbingan Konseling, Vol 4, No. 1, 67-74

Rusdi Sufi, et al. (2015). Asal Usul Aceh Barat, Aceh Barat, Bapeda Aceh Barat, 2015.

Shelly Aprillia. (2015). Pelaksanaan Pengasuban Anak Usia Dini di tempat penitipan Anak (TPA) Dharma YogaSanti Yogyakarta, Skripsi Jurusan PendidikanLuar Sekolah Fakultas Ilmu Pendiudikan Universitas Negeri Yogyakarta.

Syamsu Yusuf. (2010). Psikologi Perkembangan anak dan Remaja,Bandung: Remaja Rosdakarya.

Sri Lestari. (2013). Psikologi Keluarga Penanaman Nilai dan Penanganan Konflik Dalam Keluarga,Jakarta: Kencana Prenada Media Group.

Siti Rodliyah. (2017). Pengalihan Pengasuban Anak Orang Tua Karir, Skripsi Jurusan Hukum Keluarga Islam, Fakultas Syari'ah, Institut Agama Islam Negeri (IAIN) Salatiga.

Sugiyono. (2010). Metode Penelitian Kuantitatif, Kualitatif dan R\&D, Bandung: Alfabeta.

Suharsimi Arikunto. (2006). Prosedur Penelitian, Jakarta: Rineka Cipta. 
Sujadi, E. (2017). Penerapan Pendidikan Karakter Cerdas Format Kelompok Untuk Meningkatkan Nilai Kejujuran Mahasiswa Bimbingan Konseling Islam (BKI) Institut Agama Islam Negeri (IAIN) Kerinci. Tarbawi : Jurnal Ilmu Pendidikan, 13(1), 97-108

Sujadi, E., \& Wahab, M. (2018). Strategi Coping Korban Bullying. Tarbawi : Jurnal Ilmu Pendidikan, 13(2), 21-32.

Zohrotul Layliyah. (2013). Perjuangan Hidup Single Parent, Jurnal Sosiologi Islam, Vol. 3, No.1, ISSN: 2089-0192.

Zulfan Saam, M.S, Sri Wahyuni. (2012). Psikologi Keperawatan, Jakarta, PT Raja Grafindo Persada. 